\title{
Methods of Improving Water Treatment Systems for Individual Residential Houses
}

\author{
Sergey Pavlov ${ }^{1}$, Alexander Novikov ${ }^{1, *}$, Alexander Pavlov ${ }^{1}$, Olga Skvortsova ${ }^{1}$, \\ Olga Nikonova ${ }^{1}$, Ekaterina Semanina ${ }^{1}$, Ruslan Zafarov ${ }^{1}$ and Karl-Otto Wenkel ${ }^{2}$ \\ ${ }^{1}$ Peter the Great St. Petersburg Polytechnic University, 195251 Polytechnicheskaya str. 29, \\ St. Petersburg, Russia \\ ${ }^{2}$ Leibniz-Centre for Agricultural Landscape Research, EberswalderStraße 84, Müncheberg, 15374, \\ Germany
}

\begin{abstract}
One of hot topics for ecological management is sewage treatment today in places where there is no sewerage. The volume of country construction in territories, which are not connected to the public sewage system increasing nowadays. Therefore, problem of wastewater treatment take place. Currently, there are a lot of different designs of local waste treatment plants is offered to consumers. However, a large number of negative reviews indicate serious shortcomings in most of the local plants offered in the market. The purpose of this paper is the proposal of improvement of the most common local treatment plants in Russia.
\end{abstract}

\section{Introduction}

For the reason of treatment plants development and improvement, it seems necessary to solve the following problems:

1. Offer classification of local waste treatment plants because of their various operation and serious constructive differences.

2. If it is possible, identify the advantages and disadvantages of the local waste treatment plants. For this purpose, take one or several units of each group. Creators present the following disadvantages: a) lack of necessary or desirable elements to provide highquality process of clearing; b) elements in the system which are almost not influence on the quality of clearing, make the price of the clearing system higher; c) lack of official document confirming the compliance of the treated wastewater accepted by sanitary standards in this region. For example, in the Russian Federation such standards are SanPiN 2.1.5.98-00 "Hygienic requirements for surface water protection" ; d) the absence of wellcomposed guide which describes the device and operation of the cleaning plant.

3. Analysis of advantages and disadvantages offers how to improve design and make the cleaning systems of this group cheaper.

\footnotetext{
*Corresponding author: coolhabit@yandex.ru
} 


\section{Method}

Classification of treatment plants is based on standard wastewater treatment procedure. This scheme includes the following steps: clarification (gratings, grit chambers, presettling tanks), biological treatment (aerotanks or trickling filters also possible anaerobic treatment in septic tanks), final settling tank (the systems of moving of recurrent and surplus sludge in case of aerotanks, system of processing waste activated sludge or biofilm, disinfection of treated waste water, removal of treated waste water into the intake channel or in the soil [1, 2].

On the basis of data about the treatment plants available to the authors, we propose the following classification.

\subsection{Group 1 - Plants, including the aeration tank and secondary settler}

Installation represents aerotank only with a secondary settler; primary settler is missing. There are no trash-rack structure and disinfection of treated wastewater. Division into excess and return sludge is not presented. All activated sludge from the secondary settling tank is fed back into the aeration tank. If the concentration of waste activated sludge above the limit, plant stops and the most part of sludge is taken out by cesspool transport. The purification steps: 1) supply the waste water to the plant; 2) inflow of waste water in the aeration tank and the processing by activated sludge; 3) settling of activated sludge and contaminants in the secondary settling tank which have passed through the aeration without changes; 4) export the purified organic and supernatant water by gravity into the ground.

There is an example of the installation related to this group "Independent Sewerage SANI"(Fig. 1).

This plant represents concentric volumes. The inner volume represents the conical chamber with a hole at the bottom, filled with the elements covered by micro-organisms that consume organic matter dissolved in the waste water. Air moves into this capacity. External volume serves (according to the description) as a settler where a sedimentation of the fractions which are not exposed to biological cleaning take place. This plant represents the simplified version of the biofilter by the principle of action $[3,4]$.

The efficiency of the plant is questionable. Waste water on loading with a biofilm has to be pumped by a drop irrigation, but not a continuous stream in the classical version of the biofilter which provides a 95-percent cleaning of organic chemistry. Primary settler is required for biofilter. The pores between the loading elements quickly clogged with large fractions of waste which is contained in the waste water without primary settler. The settler does not be able to release the waste water from the slurry. The stream moving the fractions intended to precipitation (they have to move down) directed upwards to an interceptor [5]. The code certificate «736 The main center of state sanitary and epidemiological supervision of the Russian Federation Ministry of Defense» of the waste water treatment plant is questionable.

It is specified that biological sorption of oxygen after cleaning decreases from $300 \mathrm{mg}$ of $\mathrm{O}_{2} / 1$ to $2 \mathrm{mg}$ of $\mathrm{O}_{2} / \mathrm{l}$, and concentration of the weighed substances decreases from 300 $\mathrm{mg} / \mathrm{l}$ to $3 \mathrm{mg} / \mathrm{l}$. How it occurs without of primary settler and with so small volume of a secondary settler is unclear.

SanPiN 2.1.5.98-00 "Hygienic requirements to protection of a surface water" is not used as a hygienic requirement. It is substituted by the unknown document according to which purified waste water shouldn't include any suspended solids at all that is impossible [6]. There is no information about bacterial pollution of the purified waste water. Also there is a question about installation design. In the technical passport of the device there is no 
description of the process of intake of waste water from aeration chamber in a secondary settler.

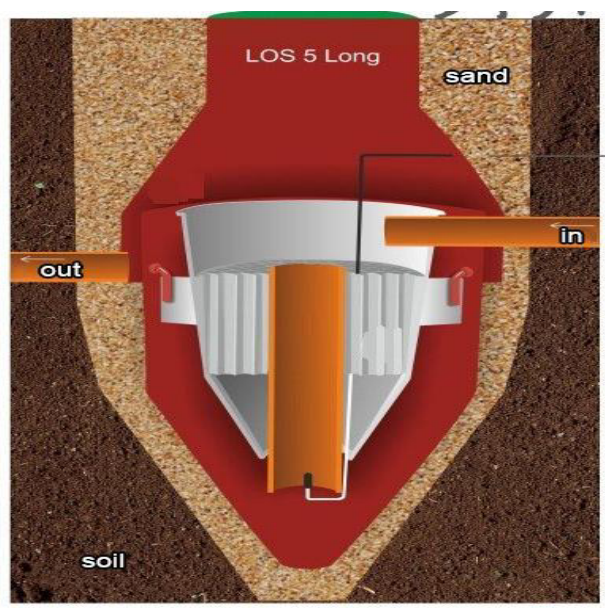

Fig. 1. Independent Sewerage SANI.

\subsection{Group 2 - The installation consisting of a uniform chamber}

The plant consists of only the aeration tank, which operates periodically, and in breaks between stages of processing waste by activated sludge, it performs the functions of the secondary settler (Fig. 2). There are no grids and disinfection is absent. These systems does not have division into excess and returnable sludge because the plant represent a single chamber and the entire sludge remains in it. If the concentration of sludge above the limit, the plant stops. A large part of the sludge is transported by Cesspool transport.

The purification steps: 1) supply of waste water to the plant; 2) faltering aeration during10 hours; 3) stage of settling during 2 hours; 4) export the purified organic and supernatant water.

The example of $2^{\text {nd }}$ group is the ONE2CLEAN plant (Fig. 2). Setting represents the uniform chamber divided by a small partition. In this plant the aerator works, oxygenating water and activating aerobic process of purification of waste water with active sludge during 10 hours. After that aeration stops and process of settling during 2 hours begins. At this time active sludge accumulates on an installation bottom, and the purified waste water is removed in the soil or to the district. According to the manufacturer, sewage can inflow in the plant during of all process. The efficiency of this plant is highly questionable. According to the manufacturer, wastewater activated by acid for elimination of a smell.

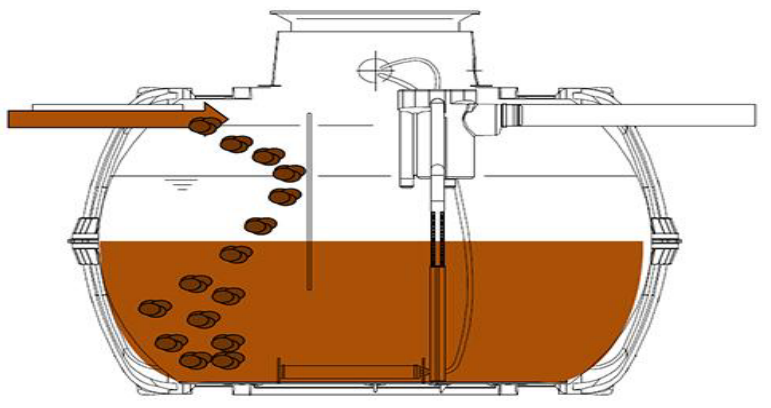

Fig. 2. ONE2CLEAN plant. 
It completely contravenes the basic principle of sewage treatment. Acid inhibits microorganisms, and as a result, sewage treatment is not performed [7]. The fact that waste water may enter the plant during settling process is doubtful. Purified water will be mixed with waste water because the chamber presents uniform capacity. The waste water received as a result of mixing can't be removed from operation [8]. The Finnish Biosetti plant also belongs to the same group (Fig. 3). The difference is only that the general amount of a chamber is divided by an impenetrable partition, and waste water is pumped from the first chamber in the second. In this plant process of purification of waste water is identical to process in the ONE2CLEAN plant. Although the movement of water and sediment is carried out at least by 3 pumps.

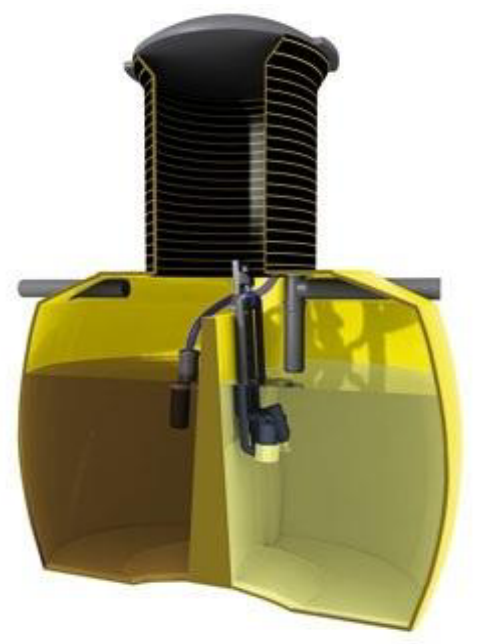

Fig. 3. Biosetti plant.

\subsection{Group 3 - Installation with the most complete set of cleaning elements}

It includes: a primary settling tank, aeration tank, secondary sedimentation tank, disinfection chamber. There are no trash screen. The camera acts as a primary clarifier and settling tank, and a septic tank. When the concentration of activated sludge in the aeration tank reaches a limit value $10.000 \mathrm{mg} / \mathrm{L}$ [9], the bulk of the activated sludge is removed. In the absence of flow of sewage in the aeration tank, the biomass contained in the sludge, according to the manufacturer, is subjected to aerobic mineralization, substantially reducing in volume. The purification steps: 1) inflow of wastewater to be treated in a primary settling tank; 2) the passage of wastewater through aeration; 3) after aeration stripped of organics but with more activated sludge water passes advocacy; 4) purified from organic and from activated sludge water passes disinfection by chlorination; 5) conclusion decontaminated water from the treatment plant to the soil or ditch.

There is "5 VOCs" is analyzed as an example (Fig. 3). Set is a complex of seriesconnected blocks, in which there is stepwise purification of waste water. First cleaning unit - primary sedimentation tank, which the role of the septic tank. In it there is a mechanical and microbiological treatment of wastewater. In the settler there is a smooth natural motion of the fluid from one chamber to another sediment through the overflow openings. Suspended solids contained in the waste water settle to the bottom and from a slang. It is subjected to slow the process of anaerobic fermentation, in which part of impurities is dissolved in water and the other at the bottom of the settler accumulates as insoluble minerals. Second cleaning unit - aeration chamber, a secondary settling tank and the 
disinfection chamber. In the aeration tank waste water using submersible aerator is saturated with oxygen. Simultaneously, there is intense mixing of aerated water. During aeration the activated sludge consumes organic compounds. After the aeration tank the water enters the secondary settling tank where activated sludge is precipitated and purified by allocating organics and water from the active sludge. Activated sludge from the secondary clarifier and primary sludge mixed with anaerobic sludge must be removed periodically. Unfortunately, the frequency of cleaning in the instructions to the VOC is not specified, which may create difficulties in the operation. The last stage of purification is disinfection of treated wastewater. Disinfection takes place at the contact of water with the tablet slow release of chlorine.

After disinfection the treated wastewater comes in ready-dispensing well, where they are displayed in the ground, if possible, or discharged off-site. Installing such plants, it should pay attention to temperature control area. The manufacturer points out that for the effective operation of the primary sump (used as a septic tank) needs to make its insulation. It is also necessary to make pipe insulation; the temperature in the waste water was between 15-30 $\mathrm{C}^{0}$. Datasheet waste water treatment plant VOC 5 up with great care. In it painted in great detail the waste water treatment process. Each element of the installation is painted in detail, and how it is involved in the cleaning process. Also, manufacturers are given very detailed instructions on the installation and operation of the facility, as well as instructions in case of malfunction. Certificate of compliance for treated waste water sanitary norms and rules beyond doubt.

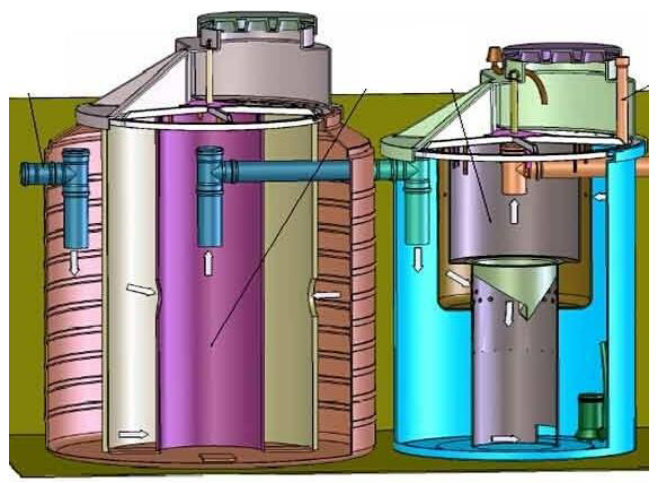

Fig. 4. LOS 5 plant.

"YUNILOS Mega M-30" refers to the same group of installations (Fig. 5). YUNILOS "MEGA-M-30" plant consists of a series-connected units: 1) block the mechanical purification of waste water; 2) the unit of biological treatment in aeration tanks and the bioreactor, with the participation of attached and free-floating microorganisms; 3) block additional cleaning and disinfection; 4) block sludge dewatering. First, the waste water flows into the sewage pumping station, after that they enter the mechanical grates, where the wastewater treatment of the coarse inclusions of size greater than 1-2 mm. Apparently (this is in the "Description" is not mentioned), lattice are equipped with mechanical rakes to remove the dirt from the rods. Then drain enters the biological treatment unit. In this unit, it first enters the homogenization tank where they are mixing and the averaging effluent occurs then it enters the denitrifies wherein biological coagulation occurs.

On this occasion, you will notice that there is a process of bio-coagulation under aeration of wastewater (without oxygen activated sludge is not working [10]), while denitrification is a process of anaerobic $[11,12]$. As a single device can be carried out two different nature of the process - is unclear. 
Then, the mixture of sewage and activated sludge flows into a biological purification unit, which in turn provides sequential process deeper mineralization of organic substances. In the first section by maintaining anoxic oxygen regime and high loads on the mud to develop a culture of microorganisms, as a result of vital activity which occurs enzymatic hydrolysis of organic matter [13]. In fact, this element is a septic tank [14].

Next brightened waste water enters the aeration tank, in which the biochemical oxidation of organic substances of activated sludge microorganisms using dissolved oxygen. Aeration tank includes an anaerobic denitrification zone (in the diagram in the "Description" in the anaerobic denitrification zone somehow fed air) and the aerobic nitrification zone.

Aerobic nitrification zone allows the oxidation of organics. The mixture of purified water and activated sludge flows into the aeration tank after the secondary clarifier. Il settles in a secondary settling tank; part of it through the air lift system is given, as stated in the "Description" in the septic chamber primary settling tank.

Primary settler is not mentioned in the text above and in Scheme absent. Apparently it meant "block of deep mineralization" (septic tank). Another part of the activated sludge is returned to the aeration tank. Secondary clarifier effluent from the bioreactor fall with floating on the surface of which is formed and fixed biofilm microorganisms contributing to the ultimate oxidation of the organic contaminants. The effectiveness of this element is questionable, as in classical biofilters for quality treatment of wastewater from organic drip irrigation elements required to boot from a biofilm and intensive air blowing [15].

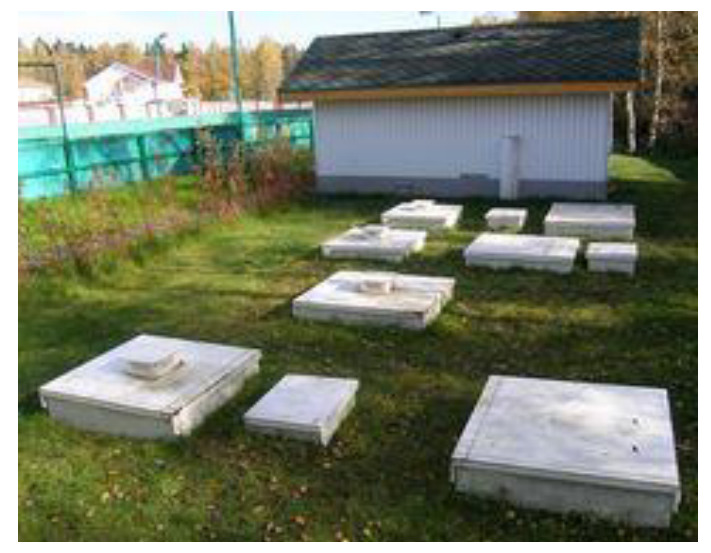

Fig. 5. YUNILOS Mega M-30 plant.

After bioreactor clarified juice enters the tertiary settling tank for the final settling and going on to post-treatment advanced treatment and disinfection unit. To do this, apply a filter and sorption floating load. Purified water is supplied for the installation of ultraviolet disinfection and diverted to the intake channel. In biological purification coagulant is added to the sump for removing phosphate solution.

The excess activated sludge system is going to collect and remove sludge and is removed in the mineralizer provided for the collection and stabilization of primary sludge and secondary settling tanks in the anaerobic mode.

After mineralizer pellet fed to the dehydration. As part of the documents attached to the YUNILOS, there is a certificate confirming the purification of waste water to sanitary norms and rules standards. However, the document states that provided for the analysis of the original waste water is quite clear: it is the water BOD5 $=21.1 \mathrm{mg} / \mathrm{l}$ while the standard wastewater BOD5 has close to $200 \mathrm{mg} / \mathrm{l}$. 


\subsection{Group 4 - Installation with the anaerobic principle of cleaning}

Treatment plants of the Group are conducted mainly anaerobic treatment of waste water, which is followed by settling. After the anaerobic treatment of waste water can be supplied to the primitive camera aerobic treatment.

The purification steps: 1) the inflow of wastewater to be treated into the first chamber, where it takes place the anaerobic treatment; 2) bypass water in the well, which, under certain conditions, can work as a filter well; 3) the challenge of waste water from the well by gravity or pump. As an example, analyzes the Finnish plant (septic tank) Sakosetti (Fig. 6).

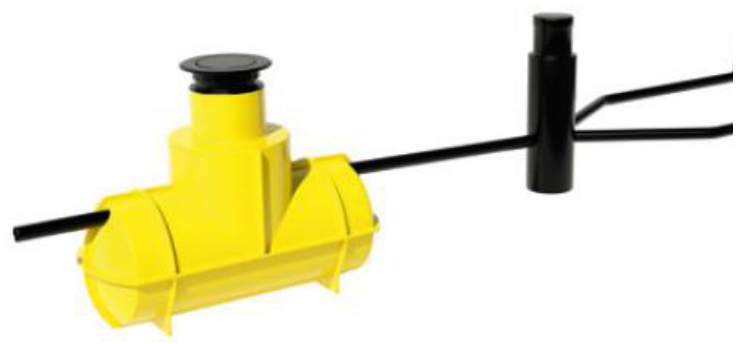

Fig. 6. Sakosetti plant.

Installation is a septic tank, connected in series with a distribution well, from which treated waste water is discharged to the filter box or off-site. The first treatment phase is deposition coarse-particulate matter, which passes inside the settling tank. From the start operation the septic tank is filled with clean water, according to the authors "Description", which allows reduce effluent concentrations which fall into it. Technologically septic tank is made so that it passes through the air.

According to the manufacturer, this is as well as reduced effluent concentrations, made for a more active involvement of the bacteria in the process of cleaning and more qualitative origin of the fermentation process. As anaerobic treatment and fermentation takes place in the septic tank of oxygen access - it is unclear [16]. The second phase of the clearing - conditionally clean water enters the septic tank after the distribution well, after that it enters the spray tube and is absorbed in a layer of crushed stone.

In it, in the oxygen-free environment it is a final post-treatment wastewater. Authors and experts in the field of wastewater treatment believe that in the soil occurs aerobic posttreatment [17], all the more that, according to the scheme "Descriptions", perforated pipe filter fields are equipped with aerators [25-28].

\section{Results and discussion}

Table 1 below systematized proposals to improve the treatment plants of different groups. Improvements are: a) addition elements that will improve the quality of treatment; b) renouncement of devices available to install, but does not improve the cleaning; c) constructive changes of existing elements in the installation. 
Table 1. Recommendations for improvement of sewage treatment plants

\begin{tabular}{|c|c|c|}
\hline & $\begin{array}{l}\text { Installation } \\
\text { example }\end{array}$ & Recommendations for improvement \\
\hline Group 1 & $\begin{array}{l}\text { Autonomous } \\
\text { sewerage Sani }\end{array}$ & $\begin{array}{l}\text { Primary settler apparatus, increase in the secondary } \\
\text { clarifier, the disinfection device camera. }\end{array}$ \\
\hline Group 2 & $\begin{array}{l}\text { Installation } \\
\text { ONE2CLEAN, } \\
\text { Biosetti }\end{array}$ & $\begin{array}{l}\text { Separation of the aeration tank and secondary } \\
\text { sedimentation chamber into two successive element, the } \\
\text { addition chamber primary settling tank, disinfection } \\
\text { chamber device. }\end{array}$ \\
\hline Group 3 & $\begin{array}{l}\text { Installation LOS } 5 \\
\text { YUNILOS Mega- } \\
\text { M } 30\end{array}$ & $\begin{array}{l}\text { In the apparatus the LOS } 5 \text { to use primary settling tank and } \\
\text { an anaerobic treatment in the chamber. For this purpose it } \\
\text { is necessary to insulate and seal the hatches, the waste } \\
\text { water fed through the elements impeding the flow of air } \\
\text { from the inlet pipe. Enlarge secondary settling tank and } \\
\text { replace the chlorination system disinfection (chlorine } \\
\text { adversely affects the chemical composition of the soil) to } \\
\text { irradiation with ultraviolet light. Cut from the system } \\
\text { YUNILOS Mega-M30 air supply to the denitrification } \\
\text { chamber. purification systems in a bioreactor with floating } \\
\text { loading replace a traditional biofilter with drip irrigation } \\
\text { fixed crushed stone or plastic boot and forced ventilation. }\end{array}$ \\
\hline Group 4 & $\begin{array}{l}\text { Installation } \\
\text { Sakosetti }\end{array}$ & $\begin{array}{l}\text { Sealing chamber sump and remove it from the air supply } \\
\text { system to provide him with a septic tank functions. Do not } \\
\text { dilute the wastewater with clean water, which will provide } \\
\text { enough food for anaerobic bacteria and accelerate their } \\
\text { development. To improve the quality of the treated effluent } \\
\text { (septic removes not more than } 70 \% \text { organic matter [18]) } \\
\text { can be successively put two units. If there is no filtering of } \\
\text { treated waste water into the soil, the installation must } \\
\text { always be complemented by the disinfection system }\end{array}$ \\
\hline
\end{tabular}

General recommendations relating to the settings of all the groups in the case of operation in the North-West region is their thorough insulation. As known, for the normal functioning of aerobic (and especially anaerobic) bacteria as required sufficiently high temperature $[19,20]$.

Treated wastewater must satisfy the requirements in order that the local clearing waste treatment system would be accepted by official organizations. Authors realize that it is difficult to achieve these stringent requirements for inhabitants of country houses. As stated above, authors offer how to improve plant operation. For this purpose, authors made the analysis of the local waste treatment plants sold in the market. Due to the large number of models of clearing systems for the analysis of all models will take a lot of time. In addition, not all submitted a certificate confirming compliance with the declared and valid characteristics of wastewater treatment.

Technical passport does not contain drawings and operation of water treatment system. Also authors, describing the functional efficiency of the plant in technical passport, confirm that the plant removes up to $98 \%$ of harmful substances, what is wrong! Therefore, it is offered to divide local clearing plants into groups. Each group of units have one operation and similar design features. According to mentioned above, this work has the following results: 1) For the first time suggested the division into groups according to structural features of local treatment facilities; 2) The scheme of construction of each group was analyzed, the shortcomings identified plants; 3) The measures to improve facilities were offered. 


\section{Conclusion}

All of the sewage treatment plants are characterized by a number of design flaws that reduce the quality of treated wastewater. According to this, the researches of soil properties, which may be affected by this pollution, is also important [21-24, 29-33]. The documents attached to products, often have significant inaccuracies and errors in the descriptions of structures and processes that occur at different stages of water treatment. The proposed measures will allow authors without significant additional costs to improve the quality of waste water treatment, coming from a small village, or from an individual country house. Also received results will help to solve some problems of ecological management on purification of waste water and to improve a state of all ecological environment.

\section{References}

1. M. Henze, C.P. Leslie Grady Jr., W. Gujer, G.V.R. Marais, T. Matsuo, Water Research, 21, 505-515 (1987)

2. C.D. Beal, E.A. Gardner, N.W. Menzies, Soil Researches, 43, 781-802 (2005)

3. R. Tenno, R. Vilu, H. Oit, Automatica, 25, 739-742 (1989)

4. J.V. Voronov, S.V. Yakovlev, Vodootvedenie i ochistka stochnyh vod. Uchebnik dlya vyzov (Publisher assoxtsiatsii building schools, Moscow, 2006)

5. S.V. Yakovlev, J.A. Karelin, Kanalizaciya. Uchebnik dlya vyzov. Pyatoe izdanie (Stroyizdat, Moscow, 1975)

6. M.B. Yates, Groundwater, 23, 586-591 (1985)

7. M. Wagner, A. Loy, Current Opinion in Biotechnology, 13, 218-227 (2002)

8. P.J.A. Withers, H.P. Jarvie, C. Stoate, Environmental International, 37, 644-653 (2011)

9. M. Hummer, Tehnologiya obrabotki prirodnyh i stochnyh vod (Stroyizdat, Moscow, 1979)

10. G. Dobele, N. Bogdanovich, G. Telysheva, U. Viesturs, Applied Biochemistry and Biotechnology, 57, 857-867 (1996)

11. Y.J. Chan, M.F. Chong, C.L. Law, D.G. Hassell, Chemical Engineering Journal, 155, 1-18 (2009)

12. R.F. Hickey, W.-M. Wu, M.C. Veiga, R. Jones, Water Science \& Technology, 24, 207 255 (1991)

13. O. Legrini, E. Oliveros, A.M. Braun, Chemical Review, 93, 671-698 (1993)

14. L.J. Arnade, Seasonal Correlation of Well Contamination and Septic Tank Distance, Groundwater, 37, 920-923 (1999)

15. A.J. Balkema, H.A. Preisig, R. Otterpohl, F.J.D. Lambert, Urban Water, 4, 153-161 (2002)

16. L.S. Philippi, R.H.R. da Costa, P.H. Sezerino, Water Science and Technology, 40, 125131 (1999)

17. G. Kassab, M. Halasheh, A. Klapwijk, M. Fayyad, J.B. van Lier, Bioresource Technology, 101, 3299-3310 (2010)

18. J.V. Voronov, E.V. Alekseev, Vodootvedenie (INFRA-M, Moscow, 2012)

19. S. Luostarinen, W. Sanders, K. Kujawa-Roeleveld, G. Zeeman, Bioresource Technology, 98, 980-986 (2007)

20. H.E. Muga, J.R. Mihelcic, Journal of Environmental Management, 88, 437-447 (2008)

21. V. Badenko, V. Terleev, A. Topaj, Applied Mechanics and Materials, 635-637, 16881691 (2014)

22. S. Medvedev, A. Topaj, V. Badenko, V. Terleev, IFIP Advances in Information and Communication Technology, 448, 252-261 (2015) 
23. V.V. Terleev, A.G. Topaj, W. Mirschel, Russian Meteorology and Hydrology, 40, 278285 (2015)

24. V.V. Terleev, V. Mirschel, U. Schindler, K.-O. Wenkel, International Agrophysics, 24, 381-387 (2010)

25. V. Chechevichkin, N. Vatin, Applied Mechanics and Materials, 641- 642, 409-415 (2014)

26. N. Arefiev, V. Garmanov, V. Bogdanov, Y. Ryabov, V. Terleev, V. Badenko, Procedia Engineering, 117, 26-31 (2015)

27. A. Beljatynskij, O. Prentkovskis, J. Krivenko, Transport, 25, 394-402 (2010)

28. V.V. Okrepilov, M.V. Leonidovich, Asian Social Science, 11, 312-325 (2015)

29. V. Terleev, A. Nikonorov, V. Badenko, I. Guseva, Y. Volkova, O. Skvortsova, S. Pavlov, W. Mirschel, Advances in Civil Engineering, 2016, 7 (2016)

30. O. Skvortsova, A. Dashkina, E. Petrovskaia, V. Terleev, A. Nikonorov, V. Badenko, Y. Volkova, S. Pavlov, MATEC Web of Conferences, 53, 7 (2016)

31. V. Terleev, E. Petrovskaia, N. Sokolova, A. Dashkina, I. Guseva, V. Badenko, Y. Volkova, O. Skvortsova, O. Nikonova, S. Pavlov, A. Nikonorov, V. Garmanov, W. Mirschel, MATEC Web of Conferences, 53, 6 (2016)

32. N. Arefiev, V. Badenko, A. Nikonorov, V. Terleev, Y. Volkova, Procedia Engineering, 117, 20-25 (2015).,

33. A. Nikonorov, S. Pavlov, V. Terleev, N. Arefiev, V. Badenko, Y. Volkova, Procedia Engineering, 117, 258-263 (2015) 